\title{
Response of Three Rice Cultivars to the Intermittent Irrigation in Southern Iraq
}

\author{
Saad Flaih Hassan ${ }^{1}$, Khidhir Abbas Hameed ${ }^{1}$, Abdul Karim H. Ethafa ${ }^{2,}$, Ali NadhimKadim ${ }^{1}$, \\ Abdul Hassan Y. Abbod ${ }^{1}$, Abdul Rudha H. Ali ${ }^{1}$, Foad I. Khalil ${ }^{1}$ \\ ${ }^{1}$ Agricultural Research Directorate, Department of Rice Research, Ministry of Agriculture, Baghdad, Iraq \\ ${ }^{2}$ College of Agriculture, Department of Field Crop Sciences, University of Wasut, AL- Kut city, Iraq
}

\section{Email address:}

kirmasha1960@yahoo.com (K. A. Hameed), saadflaih@yahoo.com (S. F. Hassan)

\section{To cite this article:}

Saad Flaih Hassan, Khidhir Abbas Hameed, Abdul Karim H. Ethafa, Ali Nadhim Kadim, Abdul Hassan Y. Abbod, Abdul Rudha H. Ali, Foad I. Khalil. Response of Three Rice Cultivars to the Intermittent Irrigation in Southern Iraq. International Journal of Applied Agricultural Sciences. Vol. 1, No. 2, 2015, pp. 36-41. doi: 10.11648/j.ijaas.20150102.14

\begin{abstract}
A field trial was conducted at Al-Mishkhab Rice Research Station during 2011 season, to assess the effects of irrigation intervals on water productivity and yield components of three local rice varieties (Anber 33, Yasamin, and Furat 1). Two irrigation methods were practiced: continuous ponding and intermittent water application where irrigation water was scheduled at three different intervals (3, 5 and 7 days). The trial was performed as split plot based on a complete randomized blocks design (RCBD) having three replications. Seedlings were transplanted 20 days following germination into rows. $30 \mathrm{~cm}$ a part with $20 \mathrm{~cm}$ distance between plants within rows. The results showed that the 3-days, 5-days and 7-days intervals of irrigation consumed $50 \%, 45 \%$ and $36 \%$ as much water, as continuous flood. The 3 -days irrigation interval increased yield by $2 \%$ compared with continuous flood while the 7-days irrigation interval decreased yield by $15 \%$ compared with continuous flood. Furat1 and Yasamin varieties manifested higher water compared with Anber33. Water productivity of Furat 1 and Yasamin were $0.6108 \mathrm{~kg} \cdot \mathrm{m}^{-3}$ and $0.5667 \mathrm{~kg} . \mathrm{m}^{-3}$ respectively. It is concluded that replacing current continuous submergence of rice crops with 3-days interval irrigation will lead to a substantial saving of water, about 50\%, while raising yields; and having 7-days interval irrigation could indeed give much-improved productivity of water (grain produced per unit of water).This latter option should be considered even if it does not maximize grain produced per unit of land area in as much as water is becoming a resource more limiting than land for Iraqi agriculture. This water management strategy could help to deal with the shortage in water that is facing Iraqi farmers now and in the foreseeable future.
\end{abstract}

Keywords: Rice, Intermittent Irrigation, Water Productivity

\section{Introduction}

Water is becoming increasingly scarce, by 2025, the per capita available water resources in Asia are expected to decline by 15- 45 percent compared with 1990 (Moya et al., 2001). About $80 \%$ of the available water resources world-wide is used by the agricultural sector (Sujono, 2007), and of which irrigated rice makes the highest demand. Since rice is one of the biggest users of world's developed fresh water resources (Tuong and Bouman, 2003), it takes $3-4 \mathrm{~m}^{-3}$ to produce 1 kilogram of rice, which about 2 to 3 times higher than the amount required to produce 1 kilogram of other cereals such as Wheat or Maize (Bouman et al., 2002). To increased water productivity under increasing scarcity of water resources, intermittent irrigation has been developed as a water-saving technique and adopted in many countries such as China,
Bangladesh, and India (Xiaoping et al., 2004).Irrigation interval is of the most important ways to saving irrigation water without reducing rice areas. Irrigation water interval is to use alternate irrigations during rice growing seasons (Khalif et al., 2007). Application of intermittent irrigation can maintain or even increase grain yield because of the enhancement in root growth and grain-filling rate (Zhang et al., 2012). The results showed that it is not necessary for rice plant in all growth stages to be continuous submerge (Rahman et al., 2002).

In Iraq, the importance of rice as a staple food crop is exceeded only by wheat in terms of planted area and production. The area under rice cultivation in 2009 was 124,350 ha producing 392,800 tons, with an average yield of 3.16 tons $\mathrm{ha}^{-1}$ (MoP, 2010). Farmers' usual practice for rice production is to maintain standing water above soil surface to a 
depth of 5-20 cm throughout the rice cycle (Ahmed, 1987). Iraqi paddy farmers often store water in their fields as a backup safety measure against uncertainty in water supply, also there is often field-to-field irrigation. This leads to a high amount of surface runoff, and also has a negative effect on the environment because of the disposal of large amounts of drainage water which contain residual agrochemicals and herbicides which cause pollution of water and soil (Awan et al., 2004) and (Willingham et al., 2008).

Accordingly, we should be thinking strategically about how to change this traditional irrigation method in rice production, and maintain rice cultivation with less water. Iraqi farmers should be enabled to enhance their rice production while improving soil and environmental quality, reduce demands on limited fresh water supplies, and enhance technical skill sand agronomic understanding among rice farmers. Previous studies proved that the intermittent irrigation as an applicable strategy to overcome the consequences of new circumstance, this method can reduce water consumption and increase water productivity, while no yield loss (Rezaei and Nahvi, 2007). Singh et al., (1996) reported that maintaining a very thin water layer, at saturated soil condition, or alternate wetting and drying can reduce water requirement by about $40-70$ percent compared with continuous shallow submergence, without a significant yield loss.

The current study, therefore, was undertaken to identify the effects of water intervals duration on rice yield and its components, water productivity in condition of southern Iraq.

\section{Material and Methods}

Field trials were conducted at Al-Mishkhab Rice Research Station during 2011 season. The soil texture of the plots was silty clay loam to clay loam, calcareous soil $(23 \% \mathrm{CaCO} 3)$ with $\mathrm{pH}$ of 8.3 and EC of $1.8 \mathrm{ds} / \mathrm{m}$ (field soil analysis). Meteorological data recorded during the trials are shown in Table 1 .

Table 1. Meteorological data during the period of the trials in 2011.

\begin{tabular}{|c|c|c|c|c|}
\hline \multirow{2}{*}{ Month } & \multicolumn{3}{|c|}{ Air temperature ${ }^{\circ} \mathbf{c}$} & \multirow{2}{*}{$\begin{array}{l}\text { Evaporation from A pan } \\
\text { (mm/month) }\end{array}$} \\
\hline & Max. & Min. & Avg. & \\
\hline June & 40.8 & 24.0 & 32.8 & 531 \\
\hline July & 42.1 & 26.4 & 34.2 & 622 \\
\hline August & 41.4 & 25.0 & 33.2 & 554 \\
\hline September & 36.1 & 21.4 & 28.7 & 371 \\
\hline October & 30.7 & 17.4 & 24.0 & 254 \\
\hline \multicolumn{5}{|c|}{ Seasonal total $\mathrm{mm} \mathrm{2,332}$} \\
\hline
\end{tabular}

After preparing the soil, plots were made for each trial, $5 \times 5 \mathrm{~m}$ size. Buffer zones width were left between plots to prevent water seepage from one plot to another. Decomposed organic manure $\left(10\right.$ tons $\left.\mathrm{ha}^{-1}\right)$ was added to the plots and was mixed with the soil during ploughing. Half of the recommended quantities of chemical fertilizer (CF) were applied: $140 \mathrm{~kg} \mathrm{ha}^{-1}$ of urea and $200 \mathrm{~kg} \mathrm{ha}^{-1}$ of NP as compound fertilizer (18-18). Hand weeding was regularly adopted to control weeds in the plot three times after transplanting. Seedlings were prepared using plastic tray
$(3 \times 28 \times 58 \mathrm{~cm}$ in size $)$, filled with sieved soil. The amount of seeds used was $20 \mathrm{~kg} \mathrm{ha}^{-1}$ for seedlings produced.

The trial was performed as split plot based on a complete randomized blocks design (RCBD). The sowing date was June 19.

Continuous standing water $(7-8 \mathrm{~cm})$ was maintained in all the treatments up to 20 days after transplanting to avoid preapprehended weed infestation that could be awesome during crop establishment stage. For the continuous submergence method, water was thereafter applied daily to maintain a layer of water $10 \mathrm{~cm}$ deep in the plot during the entire growing season. For the intermittent irrigation, intervals of 3 , 5 or 7 days were made between successive irrigations, with approximately $8.5 \mathrm{~cm}$ of water given in each irrigation. Amount of applied water was measured using water meter. Water productivity was obtained by comparing the water consumption for one planting season to yield data (kg yield/ $\mathrm{m}^{3}$ water) (Chapagain et al., 2011).

At maturity, plants were sampled diagonally across $3 \mathrm{~m}^{2}$ harvested areas per plot to determine grain yield. Also, 10 randomly-selected rice panicles were sampled from each plot for determination of yield components. Means were compared by the least significance difference (LSD) method evaluated at the $5 \%$ level of confidence. Statistical tests were conducted using the Gen stat (Ireland, 2010) analysis method.

\section{Result and Discussions}

\subsection{Plant Growth Characteristics}

\subsubsection{Plant Height}

Table 2 indicates that the plant height as affected by irrigation method

Table 2. Plant height (cm) with different irrigation regimes.

\begin{tabular}{lllll}
\hline Irrigation method & $\begin{array}{l}\text { Variety } \\
\text { Anber33 }\end{array}$ & Yasamin & Furat1 & Mean \\
\hline Cont. subm. & 132.00 & 81.00 & 70.00 & 94.33 \\
3 d intervals & 142.67 & 88.44 & 73.33 & 101.33 \\
5 d intervals & 124.00 & 76.67 & 66.33 & 88.67 \\
7 d intervals & 114.67 & 70.67 & 62.67 & 82.67 \\
Mean & 128.33 & 79.17 & 67.75 & \\
LSD(0.05) & Irrigation(1.96) Variety(3.31) Interaction(5.60) \\
\hline
\end{tabular}

The results in this table showed that the highest average plant height was obtained with intermittent irrigation 3 days intervals was $(101.33 \mathrm{~cm})$, while the lowest with 7 day interval has $(82.67 \mathrm{~cm})$ as average. This result may be attributed to rotational irrigation of the fields allows for good aeration of the soil and better root growth with 3 days interval, and water stress with 7 days interval. Similar results was reported by (Styger, 2009).Rahman et al.,(2002) reported that plant height was decreased with increasing water stress(Tuong et al., 2005).

The varieties showed their own differences in this characteristic, the average highest plant height reached to $(128.33 \mathrm{~cm})$ with Anber33 variety, while the lowest $(67.75 \mathrm{~cm})$ with Furat1 variety. This was probably caused by genetic factor rather than cultural practices. 
The interaction between the varieties and the intermittent irrigation as showed in the table, also affected plant height significantly. The highest plant height of Anber33 $(142.67 \mathrm{~cm})$ was obtained with 3day interval, and the lowest plant height of Furat1 $(62.67 \mathrm{~cm})$ with 7 days interval.

\subsubsection{Active Tillers Number Per $\mathrm{m}^{2}$}

There were clear and significant differences in active tillers number per $\mathrm{m}^{2}$ as seen in table 3.The average of highest active tillers number was (276.9)with 3 days interval, while the lowest was(228.9) with continuous submergence. This result may be attributed to the reduction in the number of tillers under continuous submergence was mainly attributed to less oxygen supply that inhibits tillering and growth of tiller buds. Similar result was reported by Choi et al.,(2004) that the tendency of increase in tiller number affected by depth during sallow intermittent irrigation.

Table 3. Active tillers number per $m^{2}$ with using different irrigation regimes.

\begin{tabular}{lllll}
\hline \multirow{2}{*}{$\begin{array}{l}\text { Irrigation } \\
\text { method }\end{array}$} & Variety & & \multirow{2}{*}{ Mean } \\
\cline { 2 - 4 } Anber33 & Yasamin & Furat1 & \\
\hline Cont. subm. & 177.3 & 233.3 & 276.0 & 228.9 \\
3 d intervals & 288.7 & 253.3 & 288.7 & 276.9 \\
5 d intervals & 225.0 & 255.7 & 298.3 & 259.7 \\
7 d intervals & 231.7 & 246.7 & 281.7 & 253.3 \\
Mean & 255.7 & 247.2 & 286.2 & \\
LSD $(0.05)$ & Irrigation(20.53) Variety(13.22) Interaction(27.50) \\
\hline
\end{tabular}

The varieties showed in the table significant differences in this characteristic, Furat1 recorded the highest active tillers number (286.2), with Yasamin giving the lowest Active tillers number reached (247.2). This was probably caused by genetic factor.

The interaction between the varieties and the intermittent irrigation as showed in the table, also affected active tillers number per $\mathrm{m}^{2}$ significantly. The active tillers number reached (298.3) of Furat1 was obtained with 3 days interval, and the lowest active tillers number of Anber33 (177.3) with continuous submerge.

\subsubsection{Biological Yield}

There were clear and significant differences in this characteristic as seen in table 4 . The average of highest biological yield was (1052.2 g.m $\left.{ }^{-2}\right)$ with 3 days interval, while the lowest was $\left(956.2 \mathrm{~g} \cdot \mathrm{m}^{-2}\right)$ with 7 days interval. This result may be attributed to the better growth condition with more nutrients caused high grain weight and tillers numbers above-ground biomass. Similar result was reported by Azarpour et al.,(2011) mentioned that the highest biological yield was obtained by more interval irrigation.

Table 4. Biological yield $\left(\right.$ g. $\left.\mathrm{m}^{-2}\right)$ using different irrigation regimes.

\begin{tabular}{lllll}
\hline $\begin{array}{l}\text { Irrigation } \\
\text { method }\end{array}$ & Variety & & \multirow{2}{*}{ Mean } \\
\cline { 2 - 4 } Anber33 & Jasmine & Furat1 & \\
\hline Cont. subm. & 615.3 & 1154.0 & 1175.3 & 981.6 \\
3 d intervals & 744.3 & 1066.0 & 1347.3 & 1052.2 \\
5 d intervals & 887.7 & 885.7 & 1155.7 & 976.3 \\
7 d intervals & 897.7 & 915.3 & 1056.7 & 956.2 \\
Mean & 786.2 & 1005.5 & 1183.5 & \\
LSD(0.05) & Irrigation(34.81) Variety(43.94) Interaction(76.48) \\
\hline
\end{tabular}

The varieties showed in the table above significant differences in this characteristic, the average highest biological yield reached to $\left(1183.5 \mathrm{~g} . \mathrm{m}^{-2}\right)$ with Furat1 variety, while the lowest $\left(786.2 \mathrm{~g} \cdot \mathrm{m}^{-2}\right.$ )with Anber33 variety. This was probably caused by high grain weight and tillers numbers with Furat1, and also by genetic factor.

The interaction between the varieties and the intermittent irrigation method as showed in the table, also affected biological yield significantly. The highest biological yield $\left(1347.3 \mathrm{~g} \cdot \mathrm{m}^{-2}\right)$ of Furat1 was obtained with 3 day interval, and the lowest biological yield of Anber33 (615.3g. $\left.\mathrm{m}^{-2}\right)$ with continuous submerge.

\subsection{Yield Components}

\subsubsection{Number Grain Per Panicle}

The results shown in Table 5 indicate that the number of grains per panicle was definitely affected when the irrigation method was changed from continuous submergence to irrigation with intervals of 3,5 or 7 days. Average highest grain number per panicle was (141.2) with 3 day interval, while the lowest was (121.7) with 7 day interval. This result may be attributed to the nutrient availability for plants due to microorganisms' activities in soil and also greater shading of leaves in 3 days interval irrigation than other irrigation treatments.

Table 5. Number grains per panicle with different irrigation regimes.

\begin{tabular}{lllll}
\hline Irrigation & \multicolumn{3}{l}{ Variety } & \multicolumn{2}{c}{ Mean } \\
\cline { 2 - 4 } method & Anber33 & Yasamin & Furat1 & \\
\hline Cont. subm. & 146.2 & 136.0 & 135.1 & 139.1 \\
3 d intervals & 147.3 & 140.5 & 135.9 & 141.2 \\
5 d intervals & 140.3 & 131.6 & 146.0 & 139.3 \\
7 d intervals & 121.9 & 119.2 & 124.2 & 121.7 \\
Mean & 138.9 & 131.8 & 135.3 & \\
LSD(0.05) & Irrigation(10.16) Variety(NS) Interaction(NS) \\
\hline
\end{tabular}

The varieties showed slightly reduced but no different significant in number of grains per panicle, the average highest number was (138.9) with Anber33, and the lowest was (131.8) with Yasamin variety as an average.

The interaction between the varieties and the intermittent irrigation as showed in the table, no differences were noticed in this characteristic.

\subsubsection{Grain Weight}

It appeared clearly from the table 6 that the 1000 grains weight was slightly affected by irrigation method. The average of highest 1000 grain weight was (22.11 g) with continuous submergence, while the lowest was(21.00 g) with 7 day interval irrigation. This result may be attributed to the continuous flood enhance water availability and nutrients absorption along the growing season. A further reduction in the irrigation period could result in a salinity build up which affect 1000-grain weight (Sepaskhah and Yousfi-Falakdeli, 2009). Similar result was reported by (Saleh et al.,1999). 
Table 6. 1000-grain weight (g) for three rice varieties under different irrigation Practices.

\begin{tabular}{lllll}
\hline $\begin{array}{l}\text { Irrigation } \\
\text { method }\end{array}$ & Variety & & Mean \\
\cline { 2 - 4 } & Anber33 & Yasamin & Furat1 & \\
\hline Cont. subm. & 20.67 & 21.00 & 24.67 & 22.11 \\
3 d intervals & 20.67 & 21.00 & 24.00 & 21.89 \\
5 d intervals & 19.67 & 20.33 & 24.00 & 21.33 \\
7 d intervals & 19.67 & 19.67 & 23.67 & 21.00 \\
Mean & 20.17 & 20.50 & 24.08 & \\
LSD $(0.05)$ & Irrigation(0.46) Variety(0.45) Interaction(NS) \\
\hline
\end{tabular}

Furat1variety gave the highest 1000-grain weight (24.08 g), while Anber33 variety gave the lowest grain weight reached (20.17 g).This was probably caused by genetic factor.

No significant differences occurred due to the interaction between varieties and irrigation methods.

\subsubsection{Sterility Ratio}

The results shown in Table 7 indicate that the sterility ratio significantly affected by irrigation methods. Average of highest sterility ratio $(11.63 \%)$ was obtained with 7 days interval, while the lowest sterility ratio $(6.22 \%)$ was obtained with 3 days interval. This result may be attributed to the nutrient availability for plants due to microorganisms' activities in soil and also greater shading of leaves in 3 day interval irrigation than other irrigation treatments. Similar results was reported by Azarpour et al.(2011), who found higher sterility ratio when irrigation interval exceeded 5 days.

Table 7. Sterility ratio (\%) for three rice varieties under different irrigation regimes.

\begin{tabular}{lllll}
\hline $\begin{array}{l}\text { Irrigation } \\
\text { method }\end{array}$ & Variety & & & \multirow{2}{*}{ Mean } \\
\cline { 2 - 4 } & Anber33 & Yasamin & Furat1 & \\
\hline Cont. subm. & 14.87 & 5.80 & 5.13 & 8.60 \\
3 d intervals & 10.77 & 4.30 & 3.60 & 6.22 \\
5 d intervals & 14.93 & 5.10 & 4.93 & 8.32 \\
7 d intervals & 15.60 & 10.43 & 8.87 & 11.63 \\
Mean & 14.04 & 6.41 & 5.63 & \\
LSD $(0.05)$ & Irrigation(1.54) Variety(0.89) Interaction(1.95) \\
\hline
\end{tabular}

The varieties also showed significant differences where the average highest sterility ratio (14.04\%) was obtained with Anber33, and the lowest sterility ratio (5.63\%) was obtained with Furat1.This was probably caused by genetic factor.

Significant differences occurred due to the interaction between varieties and irrigation methods. The sterility ratio $(15.60 \%)$ of Anber33 was obtained with 7 day interval, and the lowest sterility ratio of Furat1 (3.13) was obtained with 3 days interval.

\subsubsection{Harvest Index}

The harvest index was slightly reduced by changing the method of irrigation from continuous submergence to intermittent irrigation with intervals of 5 or 7 days but with no significant effect as seen in table 8 . Where the average of highest harvest index $(0.5467)$ was obtained with 3 days interval, while the lowest $(0.5044)$ was obtained with 7 days interval. This result may be attributed to the harvest index being correlated with grain yield and biological yield, not with irrigation methods. Similar result was reported by Saleh et al.,(1999) who noticed no differences in the harvest index under intermittent irrigation. Therefore, harvest index appears to be unsuitable as an indicate of productivity of different water management practices (Ginigaddara and Ranamukhaarachchi, 2009).

Table 8. Harvest index for three rice varieties under different irrigation regimes.

\begin{tabular}{|c|c|c|c|c|}
\hline \multirow{2}{*}{$\begin{array}{l}\text { Irrigation } \\
\text { method }\end{array}$} & \multicolumn{3}{|l|}{ Variety } & \multirow{2}{*}{ Mean } \\
\hline & Anber33 & Yasamin & Furat1 & \\
\hline Cont. subm. & 0.4067 & 0.5933 & 0.6200 & 0.5400 \\
\hline $3 \mathrm{~d}$ intervals & 0.4500 & 0.5733 & 0.6167 & 0.5467 \\
\hline $5 \mathrm{~d}$ intervals & 0.4533 & 0.5567 & 0.5967 & 0.5356 \\
\hline $7 \mathrm{~d}$ intervals & 0.3600 & 0.5433 & 0.6100 & 0.5044 \\
\hline Mean & 0.4175 & 0.5667 & 0.6108 & \\
\hline $\operatorname{LSD}(0.05)$ & \multicolumn{4}{|c|}{ Irrigation(NS) Variety(0.028) Interaction(NS) } \\
\hline
\end{tabular}

The varieties also showed significant differences where the average highest harvest index (0.6108) was obtained with Furat1, and the lowest harvest index (0.4175) was obtained with Amber33. Harvest index as resulted of balance between grain yield and biological yield of the varieties.

No significant differences occurred due to the interaction between varieties and irrigation methods.

\subsection{Grain Yield}

The results shown in Table 9 indicate that the grain yield was definitely affected when the irrigation method was changed from continuous submergence intermittent irrigation. Average highest grain yield $\left(5844.5 \mathrm{~kg} \mathrm{ha}^{-1}\right)$ was obtained with 3 days interval, while the lowest $\left(4925.6 \mathrm{~kg} \cdot \mathrm{ha}^{-1}\right)$ was obtained with 7 days interval. This result may be attributed to high active tillers number per $\mathrm{m}^{2}$, number grain per panicle with less sterility ratio, also, rotational irrigation(wetting and drying) of the fields allows for good aeration of the soil and better root growth thereby increasing rice yield (Uphoff, 2006). Aguilar and Borjas (2005), concluded that irrigation treatment of 2 and 5 days after disappearance of water from surface appropriate for getting more yield.

Table 9. Grain yield $\left(\mathrm{kg}_{\mathrm{h}} \mathrm{ha}^{-1}\right)$ for three rice varieties with different irrigation regimes.

\begin{tabular}{lllll}
\hline $\begin{array}{l}\text { Irrigation } \\
\text { method }\end{array}$ & Variety & & & \multirow{2}{*}{ Mean } \\
\cline { 2 - 4 } Anber33 & Yasamin & Furat1 & \\
\hline Cont. subm. & 3150.8 & 6893.2 & 7343.2 & 5784.0 \\
3 d intervals & 3406.8 & 5976.8 & 8150.0 & 5844.5 \\
5 d intervals & 3638.8 & 5176.8 & 7456.8 & 5424.1 \\
7 d intervals & 3280.0 & 5046.8 & 6450.0 & 4925.6 \\
Mean & 3369.1 & 5773.4 & 7350.0 & \\
LSD $(0.05)$ & Irrigation(250.7) Variety(210.3) Interaction(390.3) \\
\hline
\end{tabular}

The varieties also showed significant differences, where the average highest grain yield $\left(7350.0 \mathrm{~kg} \cdot \mathrm{ha}^{-1}\right)$ obtained with Furat1 variety, While the lowest (3369.1 kg.ha- ${ }^{-1}$ ) obtained with Anber33. This was probably caused by genetic factor.

Significant differences occurred due to the interaction between varieties and irrigation methods. The grain yield of Furat1 (8150.0kg.ha $\left.{ }^{-1}\right)$ was obtained with 3 day interval, and the lowest grain yield of Anber33(3150.8 $\mathrm{kg}^{-h^{-1}}{ }^{-1}$ was 
obtained with continuous flood.

\subsection{Irrigation Water}

\subsubsection{Amounts of Irrigation Water Used}

Continuous submergence consumes large quantities of water during the rice growth cycle, as seen from Table 10.

Table 10. Amount of irrigation water used $\left(m^{3} h a^{-1}\right)$ with different irrigation Treatments.

\begin{tabular}{ll}
\hline Irrigation method & Amount of water $\left(\mathbf{m}^{\mathbf{3}} \cdot \mathbf{h a}^{\mathbf{- 1}}\right)$ \\
\hline Cont. subm. & 82,630 \\
3 d intervals & 41,527 \\
5 d intervals & 36,967 \\
7 d intervals & 29,985 \\
\hline
\end{tabular}

Compared to the continuous flooding regime, the 7 days interval reduced water use $(64 \%), 5$ days interval by $(55 \%)$, and 3 days interval by (50\%). This result is in line with the result obtained by Mostafa zadeh-Fard et al.,(2010) who reported that decreasing the depth of ponding water use by about $(23 \%)$. The use of modern irrigation techniques can also lead to water saving of more than $(50 \%)$ (Saleth and Dinar, 2008).

\subsubsection{Water Productivity}

The water productivity associated with the different intermittent irrigation regimes are presented in table 11.

Table 11. Water productivity $\left(\mathrm{kg} . \mathrm{m}^{3}\right)$ with different irrigation regimes.

\begin{tabular}{|c|c|c|c|c|}
\hline \multirow{2}{*}{$\begin{array}{l}\text { Irrigation } \\
\text { method }\end{array}$} & \multicolumn{3}{|l|}{ Variety } & \multirow{2}{*}{ Mean } \\
\hline & Anber33 & Yasamin & Furat1 & \\
\hline Cont. subm. & 0.038 & 0.083 & 0.088 & 0.069 \\
\hline $3 \mathrm{~d}$ intervals & 0.082 & 0.143 & 0.196 & 0.140 \\
\hline $5 \mathrm{~d}$ intervals & 0.098 & 0.140 & 0.201 & 0.146 \\
\hline $7 \mathrm{~d}$ intervals & 0.109 & 0.168 & 0.215 & 0.164 \\
\hline Mean & 0.081 & 0.133 & 0.175 & \\
\hline $\operatorname{LSD}(0.05)$ & \multicolumn{4}{|c|}{ Irrigation $(0.00555)$ Variety $(0.00538)$ Interaction $(0.00981)$} \\
\hline
\end{tabular}

Intermittent irrigation offer beneficial to water production. From data's table above showed that the water productivity with the use intermittent irrigation practices, much higher was achieved compared with continuous submergence which were similar to the result from Choi et al.,(2004). The water productivity was seen to be $(200 \%)$ higher with 3 day intervals between water applications, and $(210 \%)$ higher with 5 day intervals, and (240\%) higher with 7 day interval compared with continuous submergence. Indeed, water productivity -- the amount of rice produced per unit of water -- was several times greater than with continuous submergence. The increasing in water productivity of intermittent irrigation was resulted from decreasing water input rather than increasing yield. With Furat-1 having the highest average water productivity $\left(0.175 \mathrm{~kg} \cdot \mathrm{m}^{-3}\right)$, followed by Jasmine $\left(0.133 \mathrm{~kg} . \mathrm{m}^{-3}\right)$, all better than Anbar33 (0.081 kg. $\left.\mathrm{m}^{-3}\right)$.

Significant differences occurred due to the interaction between varieties and irrigation methods. The highest water productivity of Furat1 $\left(0.215 \mathrm{~kg} \cdot \mathrm{m}^{-3}\right)$ was obtained with 7 days interval, and the lowest water productivity of Anber33 $\left(0.038 \mathrm{~kg} . \mathrm{m}^{-3}\right)$ was obtained with continuous flood.

\section{Conclusions and Recommendations}

Intermittent irrigation has potential to save water and increase water productivity without any significant negative impacts on rice growth and grain yield. Intermittent irrigation in rice cultivation can be used as an act of adaptation to limited water availability as well as mitigation measures against negative impacts of rice cultivation to the environment. Increasing water shortage is compelling rice farmers to develop and adapt water saving technologies. This will necessitate and encourage research on alternative measures for reducing water use and increasing the efficiency of water use in order to ensure food security.

The results of this present study showed that the quantity of water required 3 days interval is recommended for all varieties in Southern Iraq.

If water productivity is given priority, the grain yield per unit of water is more drastic reduction of water issues with 7days intervals, it gave considerably greater output from irrigation water consumed, and with water production 2.7 times greater than for continuous flood, 2.2 times more than with 5-days interval, and 2 time more than with 3-days interval. This means that there is great scope for rice production in the future even if there is a shortage of water resources in the future. This will not only enhance food security but water security as well.

We recommend investigating of the performance of shortduration varieties and drought tolerance under intervals irrigation method.

It is still necessary to have more studies for better understanding of rice reaction to drought stress.

\section{References}

[1] Aguliar, M., and F. Borjas. 2005. Water use in three rice flooding management system under Mediterranean climatic condition. Spanish Journal of Agricultural Research, 344-351.

[2] Ahmed, R.A. 1987. Agricultural crop physiology and growth under dry condition (humidity stress). Ministry of Higher Education, College of Agriculture and Forestry, Mosul University, Iraq.

[3] Awan, I., K. Hayat, C. Hassan, M. Kazmi, and N. Hussain. 2004. Effect of seedling rates and herbicides of weed dynamics. A yield of direct seeded rice. Pak. J. Weed Sci. Res. 10(3-4): 119-128.

[4] Azarpour, E., F. Tarighi, M. Moradi, and H. Bozorgi. 2011. Evaluation effect of different nitrogen fertilizer rates under irrigation management in rice farming. World Applied Science Journal, 13(5): 1248-1252.

[5] Bouman, B.A.M., H. Hengsdjk, B. Hardy, P.S. bindraban, T.P. Toung, and J.K. Ladha. 2002. Water-wise rice production. Proceedings of the International workshop on water-wise rice production, 8-11 April 2002, Los Banos, Philippines. Los Banos (Philippines): International Rice Research Institute, pp: 356. 
[6] Chapagain, T., A. Riseman, and E. Yamaji. 2011. Achieving more with less water: Alternate wet and dry irrigation(AWDI) as an alternative to the conventional water management practices in rice farming. Journal of Agricultural Science, 3(3): $3-13$.

[7] Choi, J.S., J.G. Won, D.J. Ahn, S.G. Park, and S.P. Lee. 2004. Growth and yield of rice by field water management for water saving irrigation. Korean J. Crop Sci. 49(6):441-446.

[8] Ginigaddara, G.A.S., and S.L. Ranamukhaarachchi. 2009. Effect of conventional, SRI and, modified water management on growth, yield and water productivity of direct-seeded and transplanted rice in central Thailand. Australian Journal of Crop Science, 3(5): 278-286.

[9] Ireland, C.R. 2010. Experimental statistics for agriculture and horticulture.Modula texts, CAB International, British Library, London. UK.

[10] Khalif, A.A., A.E. AbdElwahab, A.M. El-Ekhtyar, and B.A. Zaed. 2007. Response of some hybrid rice varieties to irrigation intervals under different dates of sowing. African Crop Science Conference Proceeding, 8. Pp. 67-74.

[11] MOP .2010. Annual Statistical Abstract 2008-2009. Central Bureau of Statistics and Information Technology, Directorate of Agricultural Statistics, Ministry of Planning and Development Cooperation, Baghdad.

[12] Mostafazadeh-Fard, B. F. Jafari, S. Mousavi, and M. Yazdani. 2010. Effects of irrigation water management on yield and water use efficiency of rice in cracked paddy soils. Australian Journal of Crop Science 4(3):136-141.

[13] Moya, P., L. Hong, D. Dawe, and C.D. Chen. 2001. Comparative assessment of on-farm water saving irrigation techniques workshop. Wuhan, China, 81-96.

[14] Rahman, M.T., M.T. Islam, and M.O. Islam. 2002 Effect of water stress at different growth stage on yield and yield contributing characters of transplanted a man rice. Pak. J. Biol., 5(2): 169-172.

[15] Razaei, M. and M. Nahvi. 2007. Effect of different irrigation management in clay soil on water efficiency and some features of local rice cultivars at Guilan. Agricultural Sciences Research, 9: 15-25.

[16] Saleh R.O., K.A. Jaddoa, K.A.Hameed . 1999. Water use efficiency under intermittent irrigation for rice (Oryza sativa L.) in Iraq. Paper for international conference on water resources management, use and policy in dry areas, 1-3 December, Amman, Jordan.
[17] Saleth, R. M., and A. Dinar. 2008. Quantifying institutional impacts and development synergies in water resource programs: a methodology with application to the Kala Oya Basin, Sri Lanka, Policy Research Working Paper 4498, Sustainable Rural and Urban Development Team. Washington DC: The World Bank Development Research Group, 71pp.

[18] Sepaskhah, A.R., A. Yousefi-Falakdehi. 2009. Interaction between the effects of deficit irrigation and water salinity on yield and yield components of rice in pot experiment. Plant prod. Sci. 12(2): 168-175.

[19] Singh, C.B., T.S. Aujla, B.S. Sandhu, and K.L. Khera. 1996. Effect of transplanting data and irrigation regime on growth, yield and water use in rice(Oryza Sativa L.) in Northern India. India J. Agricultural Sci., 66: 137-141.

[20] Styger, E. 2009. System of Rice Intensification (SRI): Community-Based Evaluation in Goundam and Dire Circles, Timbuktu, Mali, 2008/09. Africare, Bamako, Mali.

[21] Sujono, J. 2007. Water saving irrigation paddy fields for increasing productivity for flood reduction. In: Wilson J(ed) water resources management. Honolulu, Hawaii, USA.

[22] Tuong, T.P., and B.A.M. Bouman. 2003. Rice production in water scarce environments. In" Water productivity in Agriculture: Limits and opportunities for improvement". (EdsJ.W. Kijne, R. Barker, D. Molden), pp. 53-67. (CABI publishing, Wallingford, UK).

[23] Tuong, T.P., B.A.M. Bouman, and M. Mortimer. 2005. More rice, less water- Integrated approaches for increasing water productivity in irrigated rice-based systems in Asia. Plant Prod.Sci. 8:231-241.

[24] Uphoff, N. 2006. The System of Rice Intensification(SRI) as a methodology for reducing water requirements in irrigation rice production. International Dialogue on Rice and Water: Exploring options for food security and sustainable environments. IRRI, Los Banos, Philippines.

[25] Willingham,S.D., G.N. McCauley, S. A. Senseman, J. M. Chander, J.S. Rice, and R. K. Mann. 2007. Influence flood interval and cultivar on rice tolerance to penoxsulam. Weed Tech, 22(1): 114-118.

[26] Xiaoping, Z., G. Qiangsheng, and S. Bin. 2004. Water saving technology for paddy rice irrigation and its popularization in China. Irrig. Drain. Syst. 18: 347-356.

[27] Zhang, H., H. Li, L. Yuan, Z. Wang, and J. Zhang. 2012. Postanthesis alternate wetting and moderate soil drying enhance activities of key enzymes in Sucrose-to-Starch conversion in inferior spikelets of rice. J. Exp. Bot. 63(1): 215-227. 